\title{
Analiza sygnałów emisji akustycznej do wykrywania uszkodzeń zmęczeniowych w stali okrętowej
}

\author{
Analysis of acoustic emission signals in detection \\ of fatigue failures in steel for ship hull construction
}

\section{Streszczenie}

Uszkodzenia korozyjne i pęknięcia zmęczeniowe to główne przyczyny awarii konstrukcji wszelkich środków transportu, takich jak statki (tankowce), autocysterny i cysterny kolejowe. Oba rodzaje degradacji zarówno materiału, jak i konstrukcji są przedmiotem badań w projekcie realizowanych w ramach VII kooperacyjnego programu ramowego UE (Transport) pt. Cost effective corrosion and fatigue monitoring for transport products.

$\mathrm{W}$ artykule przedstawiono pierwsze wyniki analizy uszkodzeń zmęczeniowych z zastosowaniem emisji akustycznej (AE) przeprowadzone na materiale stosowanym do budowy statków. AE umożliwia monitorowanie propagacji pęknięć w czasie wolnozmiennych prób zmęczeniowych w warunkach asymetrycznego trójpunktowego zginania. Oczekiwano, że warunki propagacji pęknięcia zmęczeniowego będą się zmieniać od sposobu I do sposobu mieszanego I/II, co byłoby bliższe rzeczywistym warunkom pracy. Wykonano również badania zmęczeniowe z wykorzystaniem cieczy w celu określenia i oceny różnicy w propagacji fal AE poprzez ciecz i materiał będący $w$ kontakcie bezpośrednim $z$ tą cieczą. Dane pomiarowe uzyskane podczas badań zmęczeniowych zawarte są w bazie danych, wykorzystywanej do analizy metoda pattern recognition do separacji sygnałów AE pochodzących z propagacji pęknięć zmęczeniowych i korozji od tła akustycznego.

\section{Abstract}

Corrosion damages and fatigue cracks are the main causes of structural failures in all surface transport products as ships, road tankers and railway tank cars. Both types of degradation, i.e. the degradation of material and structure, are the subject of investigations carried out within the framework of a collaborative project of the 7th Framework Programme (Transport) entitled Cost effective corrosion and fatigue monitoring for transport products.

In this paper, the first fatigue tests using acoustic emission (AE) performed on ship building materials have been demonstrated. $\mathrm{AE}$ enables us to monitor the crack propagation during low fatigue tests performed on specimens under asymmetric three-point bending load. It was expected that fracture behaviour would move from Mode I to Mixed-Modes I/II, which would be closer to reality. For reference, tests were also made in liquid to obtain and evaluate the differences in $\mathrm{AE}$ waves propagation in liquid and in material directly contacting this liquid. The data obtained during fatigue tests are included in a database used in pattern recognition analysis to separate the signals due to fatigue crack propagation and corrosion damages from background noise.

\section{Wstęp}

Uszkodzenia konstrukcji statków niewykryte na czas i niemonitorowane w czasie to potencjalnie przyczyny

Mgr inż. Ireneusz Baran, inż. Marek Nowak, dr inż. Jerzy Schmidt - Politechnika Krakowska.

katastrofalnych wypadków z ogromnym zanieczyszczeniem środowiska naturalnego. Prewencyjne środki działania polegają zwykle na wykonywaniu okresowych badań i przeglądów, tak aby rozwijające się uszkodzenia zostały wykryte i zidentyfikowane na czas, co umożliwiłoby przeprowadzenie odpowiednich napraw. Jako przykład można tu przytoczyć środki transportu ropy naftowej i gazów pod ciśnieniem, które muszą być wycofane z eksploatacji w celu przeprowadzenia inspekcji 
i oględzin wizualnych oraz wymaganych badań nieniszczących (NDT). Jednakże pomimo tych wysiłków istnieje poważne ryzyko niewykrycia początku powstania uszkodzenia w ramach tych środków kontroli i może się zdarzyć, że w następnym okresie eksploatacyjnym takie uszkodzenie pojawi się i rozwinie.

$Z$ tego powodu powstało w 2008 r. konsorcjum, w skład którego wchodzą różne ośrodki badawcze, uniwersytety i spółki przemysłowe takich krajów, jak: Austria (jako koordynatora TÜV), Estonia, Niemcy, Wielka Brytania, Grecja, Polska, Portugalia i Rumunia. Konsorcjum zostało powołane do realizacji kooperacyjnego projektu w ramach VII Programu Ramowego UE (Transport) pt. Cost effective corrosion and fatigue monitoring for transport products.

Celem tego projektu jest rozwinięcie systemów okresowych badań monitorujących i instalacji stałej badań monitorujących. Przeznaczeniem obu systemów jest wykrywanie uszkodzeń materiałów konstrukcyjnych środków transportu, będących wynikiem korozji lub pęknięć zmęczeniowych.

Proponowany proces zarządzania (kontroli) stanem (stanu) jest oparty na monitorowaniu stanu technicznego konstrukcji w zakresie rozwoju pęknięć zmęczeniowych i aktywnej korozji z wykorzystaniem techniki emisji akustycznej.

Wiadomo, że AE wykrywa aktywne pęknięcia, ale również aktywną korozję, co potwierdziły także wyniki uzyskane w projekcie UE Corrosion detection of ships (EVG1-CT-2002-00067).

Dzięki zastosowaniu czujników AE zamocowanyu trwale w określonych z góry punktach newralgicznych (hot-spots) statków, cystern kolejowych i autocystern konwencjonalna strategia kontroli i badań może być zastąpiona przez bardziej opłacalny i bazujący na rzeczywistym stanie technicznym konstrukcji system wykrywania wad i uszkodzeń oraz monitoring ich rozwoju w czasie.

W tym artykule opisano część badań związanych z laboratoryjnymi badaniami zmęczeniowymi z zastosowaniem AE, materiału stosowanego w budowie statków, które zostały wykonane w ramach projektu przez Laboratorium Badań Stosowanych Politechniki Krakowskiej.

\section{Badania zmęczeniowe laboratoryjne}

Do badań zmęczeniowych na zginanie wybrano wysokowytrzymałą stal GL A32 (materiał 1.0513, LR AH32), stosowaną w budowie kadłubów statków (blachy o grubości $10 \mathrm{~mm}$ ). Właściwości wytrzymałościowe materiału otrzymano na podstawie badań laboratoryjnych na próbkach wyciętych z dostarczonych blach:

- umowna granica plastyczności w próbie rozciągania $300 \mathrm{MPa}$,

- wytrzymałość na rozciąganie $440 \mathrm{MPa}$,
- wydłużenie $50 \%$,

- umowna granica plastyczności w próbie zginania $440 \mathrm{MPa}$,

- wytrzymałość na zginanie $550 \mathrm{MPa}$.

Ogólne założenia do badań zmęczeniowych labora-

toryjnych z AE były następujące:

- próbki do badań będą miały postać dużych elementów wykonanych z blachy stalowej używanej przez stocznię remontową w okrętownictwie,

- próbki do badań będą spawane według stosowanej przez stocznię remontową technologii spawania,

- schemat obciążenia umożliwi zmianę w strefie działania karbu i wymusi przejście ze sposobu I (Mode I) do sposobu mieszanego I/II (mix mode I/II),

- częstotliwość obciążania podczas pomiarów z AE będzie się mieściła w zakresie $0,2 \div 1,0 \mathrm{~Hz}$, zgodnie z założeniami w projekcie, opartymi na rzeczywistych warunkach pracy takich konstrukcji,

- w czasie badań zmęczeniowych pomiary AE będą wykonywane $z$ wykorzystaniem czujników $A E$ zmontowanymi bezpośrednio na próbce oraz dodatkowo z czujnikami zanurzonymi w cieczy,

- ciecz będzie w bezpośrednim kontakcie z propagującym pęknięciem zmęczeniowym w celu sprawdzenia różnic $w$ falach $A E$ propagujących przez ciecz i przez materiał próbki.

$\mathrm{Na}$ podstawie przeglądu i analizy literatury, własnych symulacji MES oraz późniejszych badań wstępnych na dużych próbkach, do dalszych badań został wybrany schemat obciążenia trójpunktowego asymetrycznego zginania. Wymiary próbek, położenie spawu i karbu inicjującego oraz rozkład podpór pokazano na rysunku 1.

Pierwszym etapem były badania wstępne mające na celu weryfikację założonego schematu obciążenia.

Przeprowadzone próby zmęczeniowe wg założonego schematu trójpunktowego asymetrycznego zginania potwierdziły słuszność założenia i wymuszenie przejścia ze sposobu I (mode I) do sposobu mieszanego I/II (mix mode I/II). Na rysunku 2 pokazano przełom próbki oraz przekrój poprzeczny z widokiem propagacji pęknięcia zmęczeniowego po badaniach wstępnych.

W następnej kolejności przystąpiono do badań właściwości zmęczeniowych z pomiarem AE. Do pomiarów emisji akustycznej przyjęto system AMSY 5 z dwukanałowymi kartami pomiarowymi ASIP2 firmy Vallen Systeme $\mathrm{GmbH}$. Zastosowano dwa typy

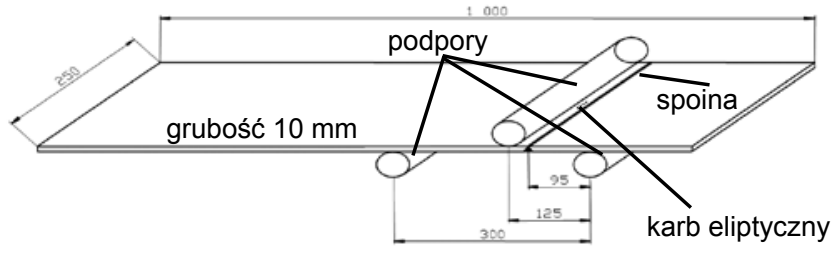

Rys. 1. Wymiary próbek zmęczeniowych i rozmieszczenie podpór $w$ trójpunktowym zginaniu

Fig. 1. The size of fatigue specimens and layout of supports for three-point bending loading 
czujników VS75 V i VS150 RIC oraz przedwzmacniacze AEP4 z wzmocnieniem 34 dB. Schemat rozmieszczenia czujników pokazano na rysunku 3.

W celu inicjacji pęknięcia zmęczeniowego zastosowano hydropulsową wytrzymałościową maszynę dynamiczną IST Systems PL400 - w tym przypadku stosowano częstotliwość obciążania w granicach do $5 \mathrm{~Hz}$, podczas gdy badania zmęczeniowe z pomiarami AE wykonywano na elektromechanicznej maszynie wytrzymałościowej ze wzmocnionym systemem obciążania Zwick Z100 - w tym przypadku stosowano częstotliwość obciążania $0,4 \mathrm{~Hz}$. Na rysunku 4 pokazano fragment typowego przebiegu obciążenia

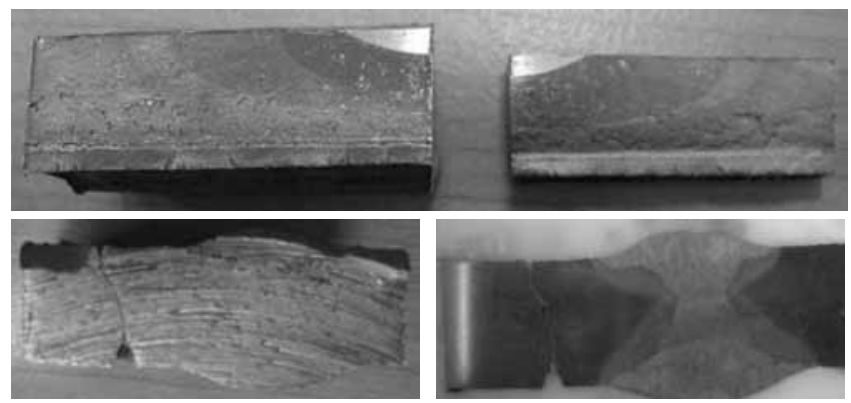

Rys. 2. Wyniki wstępnych badań zmęczeniowych - przełom próbki oraz przekrój poprzeczny z widokiem propagacji pęknięcia zmęczeniowego i spoiny

Fig. 2. The results of preliminary fatigue tests - specimen fracture and cross-section with well visible fatigue crack propagation and weld
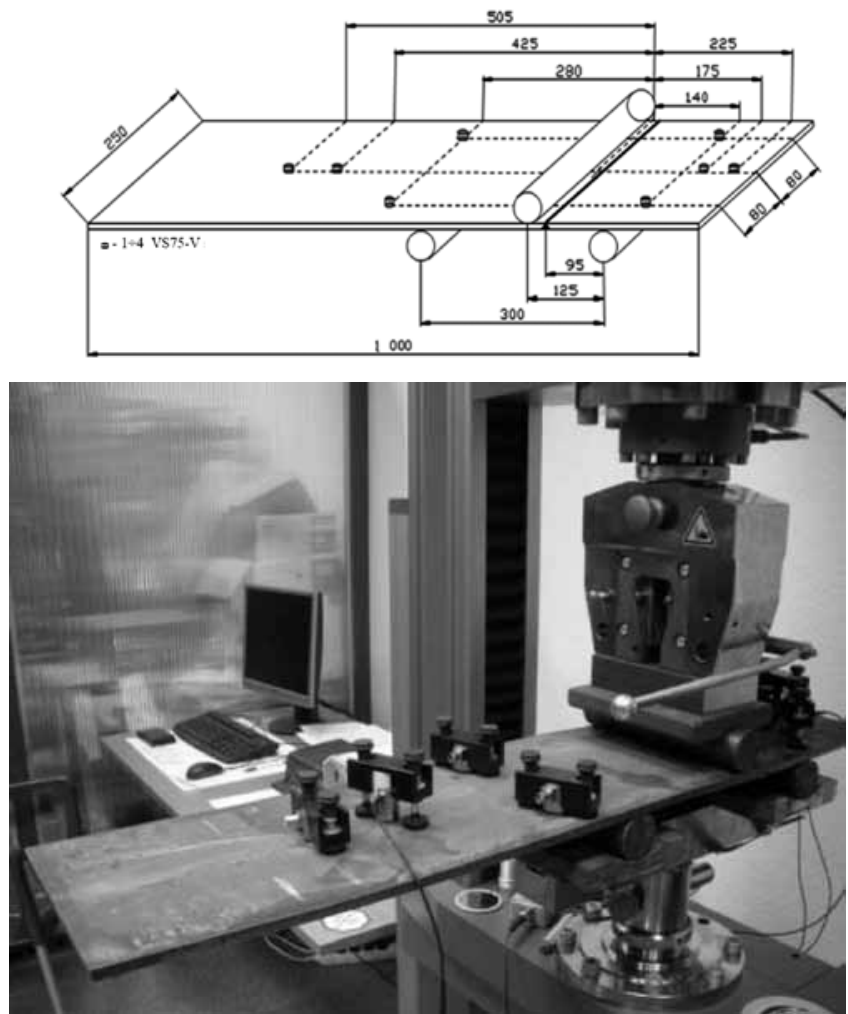

Rys. 3. Schemat rozmieszczenia czujników $A E$ wraz z podporami na próbkach do badań zmęczeniowych - fale AE przenikały tylko przez materiał próbki (metal)

Fig. 3. Schematic layout of $A E$ sensors with supports on fatigue specimens $-A E$ waves are travelling through the specimen material (metal) only zmęczeniowego w trójpunktowym asymetrycznym zginaniu oraz amplitudę rejestrowanych sygnałów $A E$, a na rysunku 5 przebieg propagującego pęknięcia zmęczeniowego w badanej próbce.

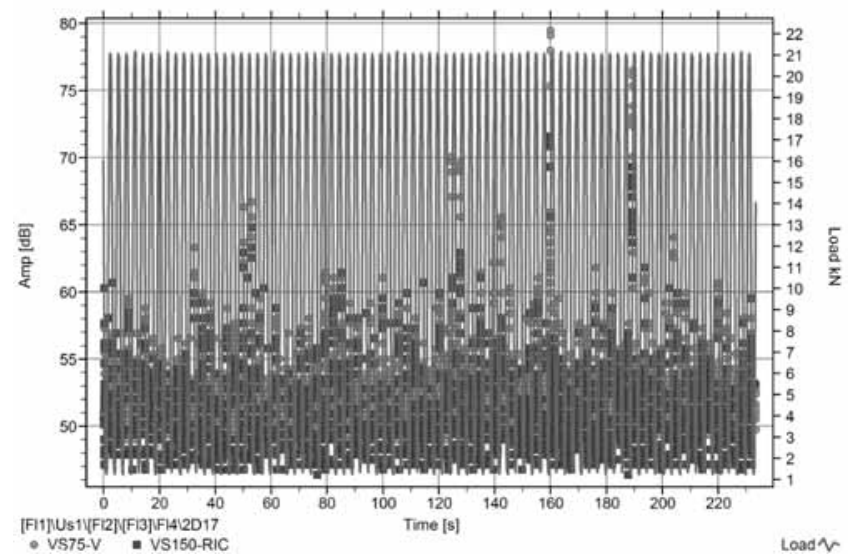

Rys. 4. Przebieg obciążenia zmęczeniowego i amplituda rejestrowanych sygnałów $A E$

Fig. 4. Fatigue loading and amplitude of recorded AE signals
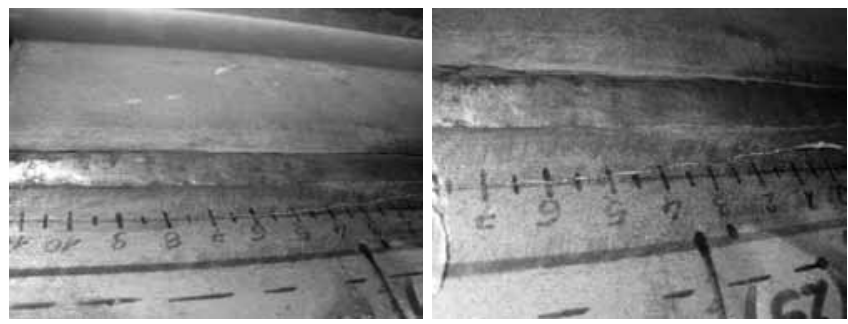

Rys. 5. Otwarte pęknięcie i kierunek jego propagacji podczas prób zmęczeniowych

Fig. 5. A Open crack and the direction of its propagation during fatigue tests
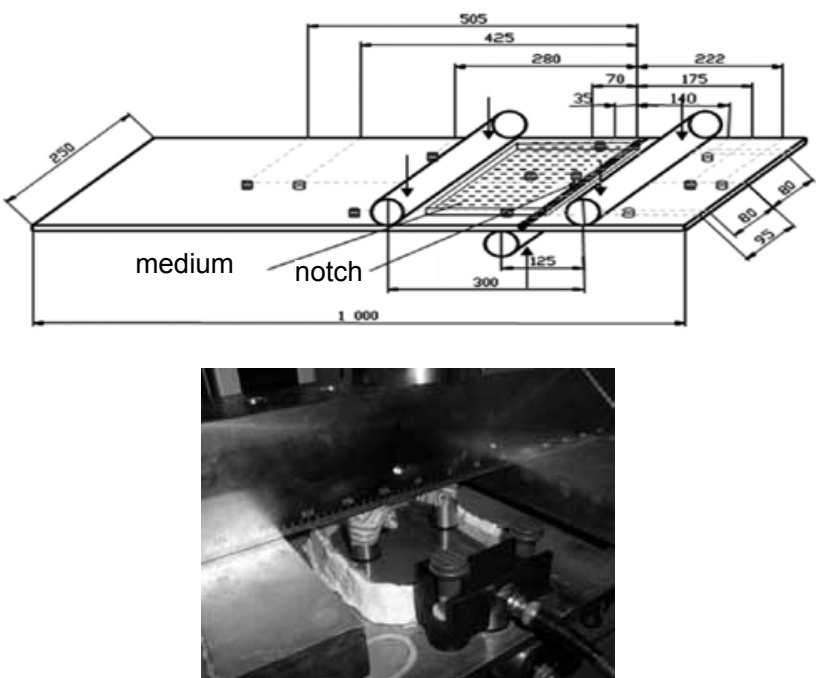

Rys. 6. Schemat rozmieszczenia czujników AE (VS75-V i VS150-RIC) wraz z podporami na próbkach do badań zmęczeniowych z czujnikami AE zanurzonymi w cieczy (tylko VS75-V) - fale AE przenikały przez materiał próbki (metal) oraz przez ciecz

Fig. 7. Schematic layout of AE sensors (VS75-V and VS150-RIC) with supports on fatigue specimens and $A E$ sensors immersed in liquid (only VS75-V) - AE waves are travelling through both specimen material (metal) and liquid 
Na tym etapie badań czujniki $A E$ były montowane tylko bezpośrednio do materiału próbki badanej wg schematu przedstawiono na rysunku 3.

Następnym etapem badań były próby zmęczeniowe $z$ pomiarami AE i czujnikami zanurzonymi w cieczy (tylko VS75-V), które były w bezpośrednim kontakcie z materiałem i z rozwijającym się pęknięciem zmęczeniowym. Schemat rozmieszczenia czujników AE pokazano na rysunku 6, a na rysunku 7 zamieszczono widok pęknięcia zmęczeniowego w badanej próbce.
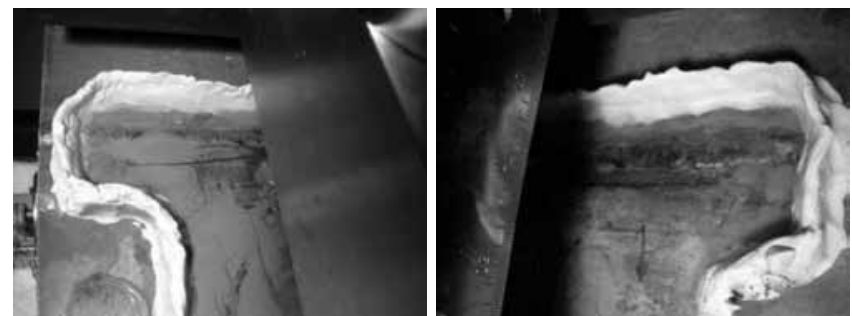

Rys. 7. Otwarte pęknięcie i kierunek jego propagacji podczas prób zmęczeniowych z cieczą

Fig. 7. Open crack and the direction of its propagation during fatigue tests with liquid

\section{Wyniki badań}

Otrzymane dane pomiarowe zostały poddane analizie i przygotowane do dalszej obróbki numerycznej, w której wykorzystano analizę metodą pattern recognition do separacji sygnałów AE pochodzących z propagacji pęknięć zmęczeniowych i korozji od tła akustycznego.

Przeprowadzono analize danych pomiarowych $z$ badań, w których czujniki AE były montowane tylko bezpośrednio na badanych próbkach (fale $A E$ przenikały tylko przez materiał - metal). Pomiary $A E$ podczas prób zmęczeniowych umożliwiły wykrycie i lokalizację pęknięć zmęczeniowych oraz monitorowanie ich propagacji wraz z kolejnymi cyklami obciążeniowymi. Na rysunku 8 pokazano lokalizację źródeł $A E$ dla czujników VS75-V. Piki (3D) oraz kwadraty (klastery) czerwony i niebieski (2D) odpowiadają wierzchołkom propagującego pęknięcia zmęczeniowego.

Następnie przeprowadzono analizę danych pomiarowych z badań, gdzie czujniki $A E$ były montowane bezpośrednio na badanych próbkach oraz zanurzone w cieczy (VS75-V). W tym przypadku fale AE przechodziły zarówno przez materiał (metal) badanej próbki, jak i przez ciecz, która była w bezpośrednim kontakcie z materiałem próbki i z rozwijającym się pęknięciem zmęczeniowym. Pomiary AE podczas prób zmęczeniowych umożliwiły wykrycie i lokalizację pęknięć zmęczeniowych oraz monitorowanie ich rozwoju wraz z kolejnymi cyklami obciążeniowymi, zarówno dla fal AE przechodzących przez materiał, jak i przez ciecz. $\mathrm{Na}$ rysunku 9 pokazano lokalizację źródeł $\mathrm{AE}$ dla czujników VS75-V. Piki (3D) oraz kwadraty czerwony i niebieski (2D) odpowiadają wierzchołkom pęknięcia zmęczeniowego.

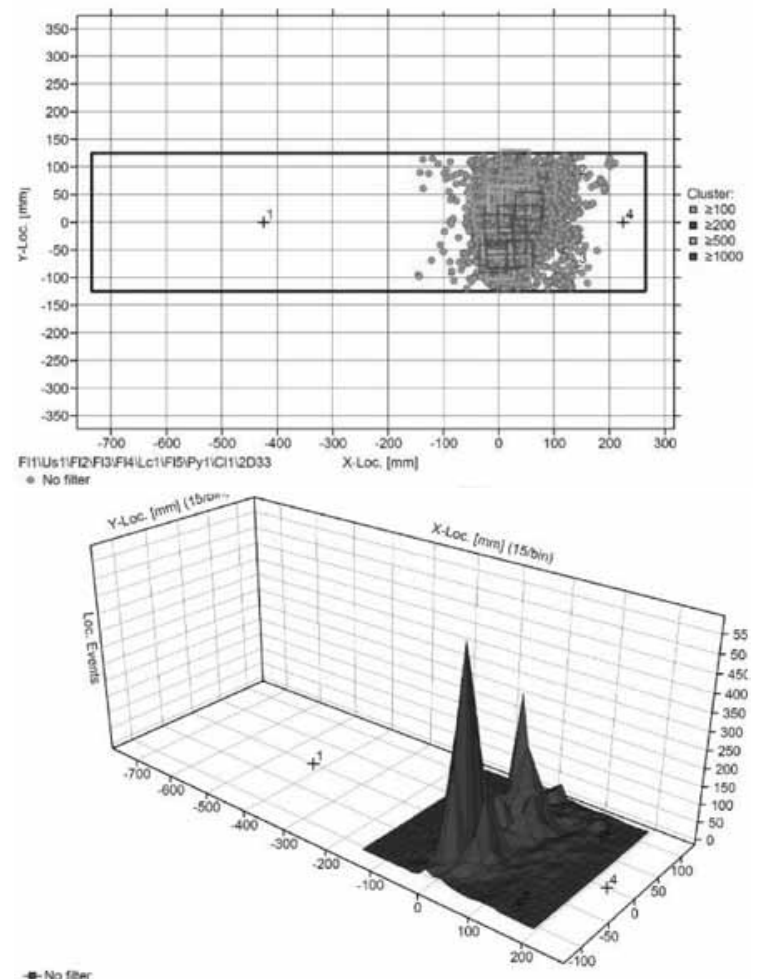

Rys. 8. Lokalizacja źródeł AE dla czujników VS75-V podczas próby zmęczeniowej (widok 2D i 3D) - fale AE przenikały tylko przez materiał próbki (metal)

Fig. 8. Location of $A E$ sources for VS75-V sensors during fatigue test ( $2 D$ and $3 D$ view) $-A E$ waves are travelling only through the specimen material (metal)
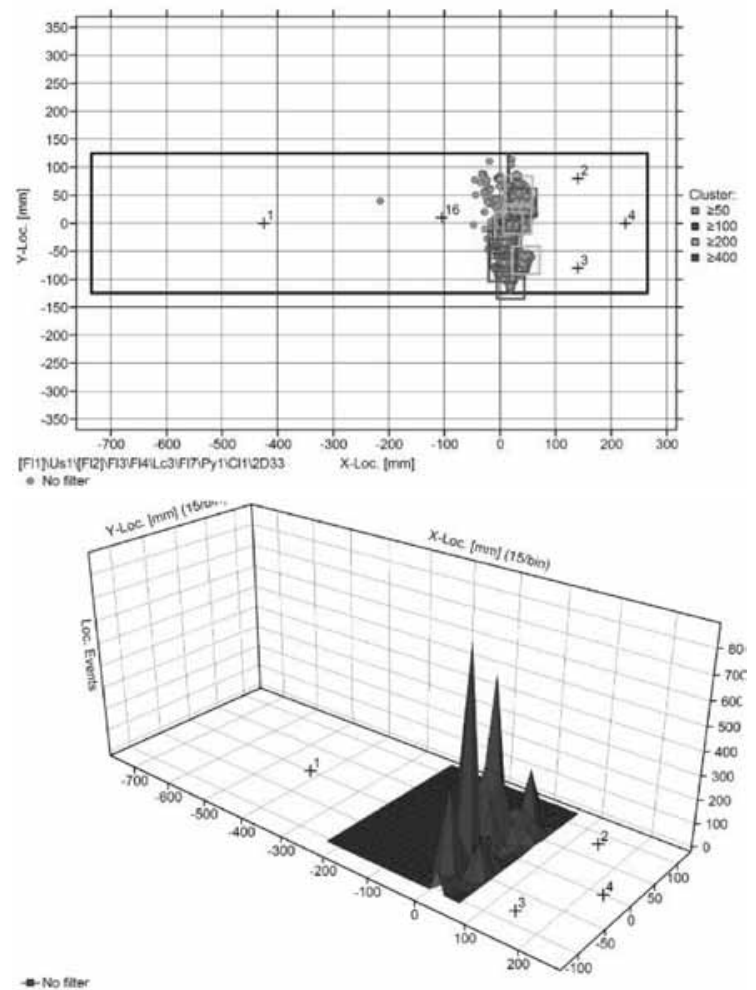

Rys. 9. Lokalizacja źródeł AE dla czujników VS75-V podczas próby zmęczeniowej (widok 2D i 3D) z czujnikami AE zanurzonymi w cieczy - fale AE przenikały zarówno przez materiał próbki (metal), jak i przez ciecz

Fig. 9. Location of AE sources for VS75-V sensors during fatigue test with $A E$ sensors immersed in liquid ( $2 D$ and $3 D$ view) $-A E$ signals are travelling through both specimen material (metal) and liquid 
Na rysunkach $10 \div 12$ przedstawiono przykłady wyniku analizy sygnałów $A E$ generowanych przez stale rozwijające pęknięcie zmęczeniowe w ponad 2500 cykli obciążenia. Na rysunku 10 pokazano lokalizację zgrupowań sygnałów AE (tzw. klasterów) wzdłuż pęknięcia zmęczeniowego oraz poziomy obciążenia (amplitude pierwszego sygnału), w których każde zdarzenie zostało wygenerowane dla określonej liczby cykli. Parametr PCTA na wykresach jest liczbą cykli obciążeń. Rysunek 11 jest wynikiem filtrowania lokalizacji z rysunku 10 i przedstawia lokalizację źródeł $A E$ dla
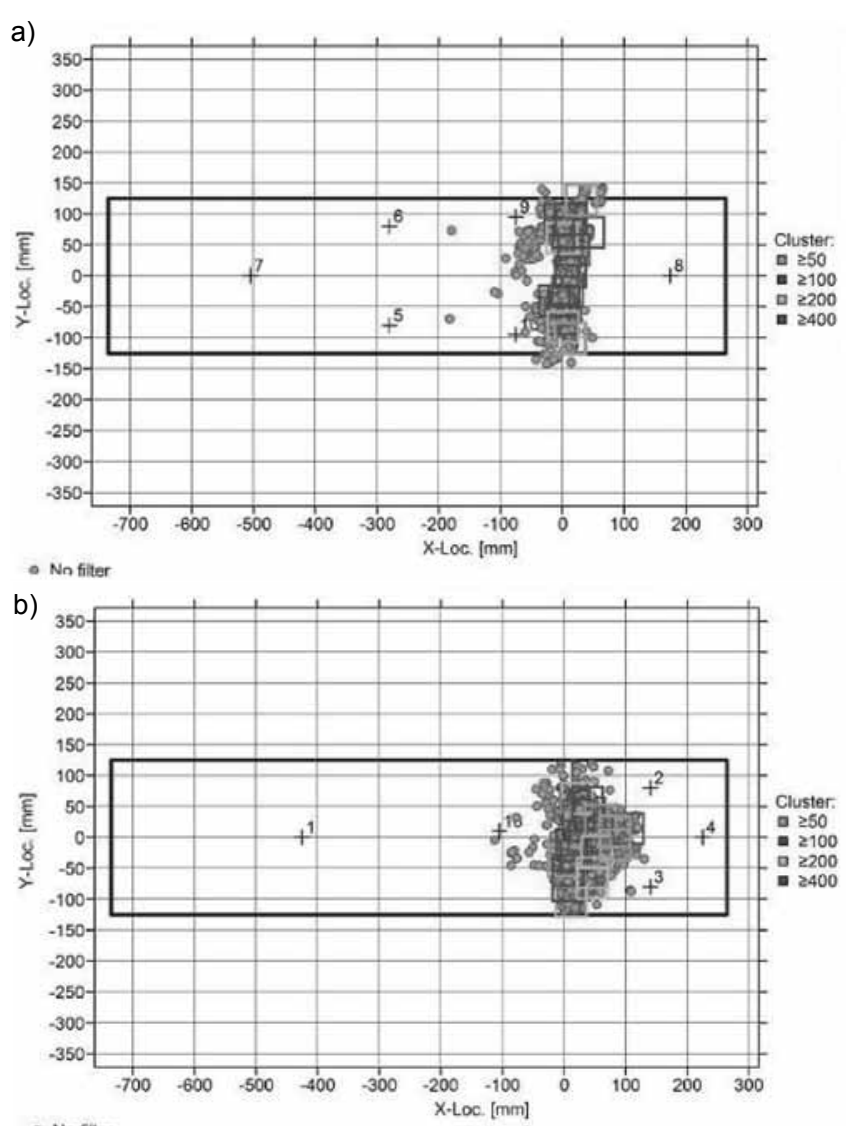

- No filter wybranych klasterów oraz poziomy obciążenia, w których każde zdarzenie zostało wygenerowane dla określonej liczby cykli. Na rysunku 12 przedstawiono przykład wyniku analizy z wykorzystaniem metody wzorców uczących w aplikacji Visual Class dla identyfikacji sygnałów AE źródeł z rysunku 11.

Widać że punkty tworzące linie lub chmu-

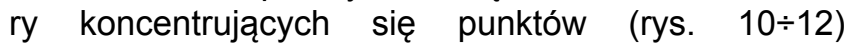
z badań dla źródeł AE zostały skojarzone przez aplikację Visual Class w tych samych indywidualnych klasach jako podobne.

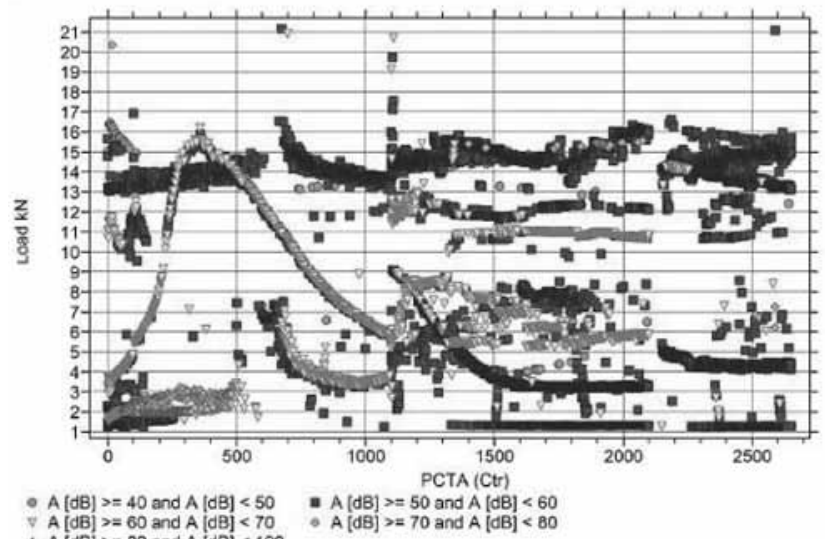

$A[\mathrm{~dB}]>=60$ and $A[\mathrm{~dB}]<70 \quad \mathrm{~A}[\mathrm{AB}]>=70$ and $\mathrm{A}[\mathrm{dB}]<B$

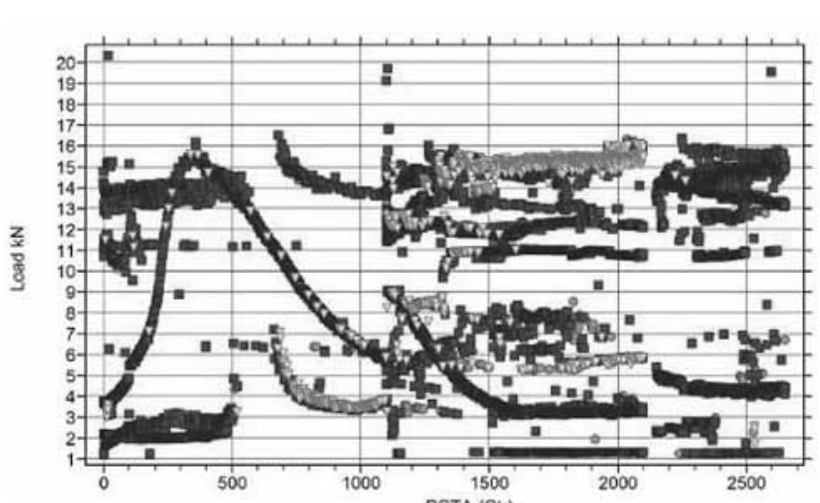

Rys. 10. Lokalizacja źródeł AE dla czujników VS150-RIC (a) i VS75-V (b) podczas testu zmęczeniowego oraz odpowiadające źródłom poziomy obciążenia i amplituda na wykresie Load vs. PCTA (ilość cykli obciążenia)

Fig. 10. Location of AE sources for VS150-RIC (a) and VS75-V (b) sensors during fatigue test and corresponding to them level of load with amplitudes of events in graph Load vs. PCTA (number of cycle loading)
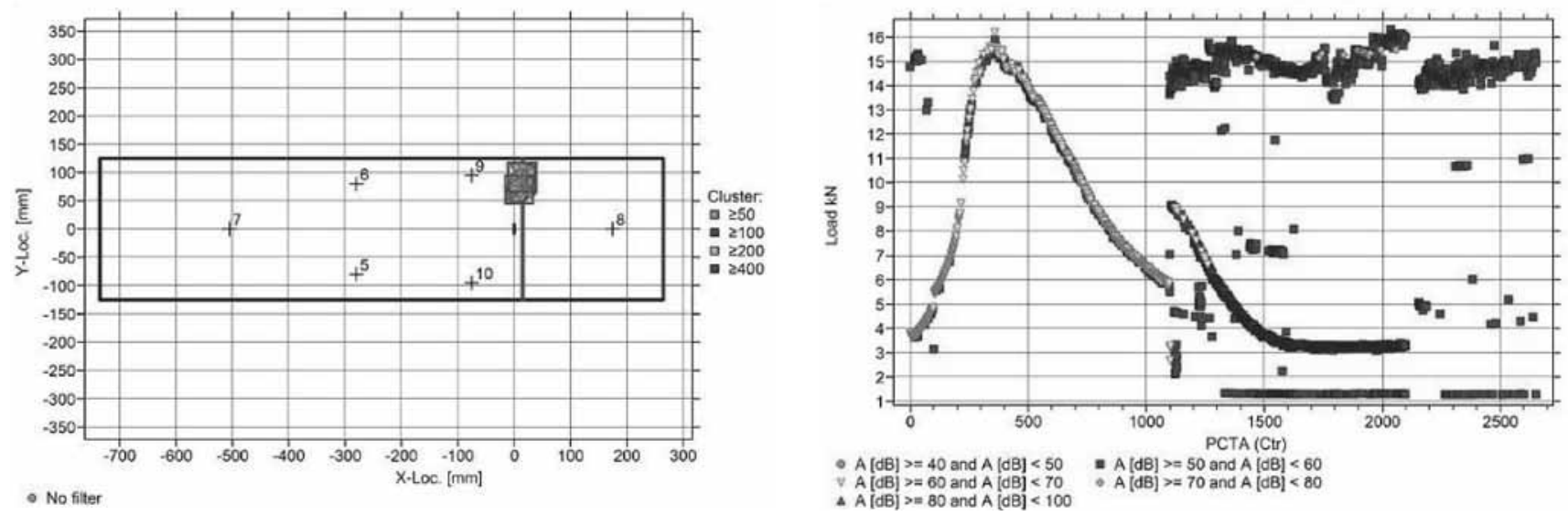

Fig. 11. Lokalizacja źródeł AE wybranego zgrupowania sygnałów (klastera) dla czujników VS150-RIC podczas testu zmęczeniowego oraz odpowiadające źródłom poziomy obciążenia i amplituda na wykresie Load vs. PCTA (ilość cykli obciążenia)

Fig. 11. Location of $A E$ source in selected cluster zone for VS150-RIC sensors during fatigue test and corresponding to them level of load with amplitudes of events in graph Load vs. PCTA (number of cycle loading) 
a)

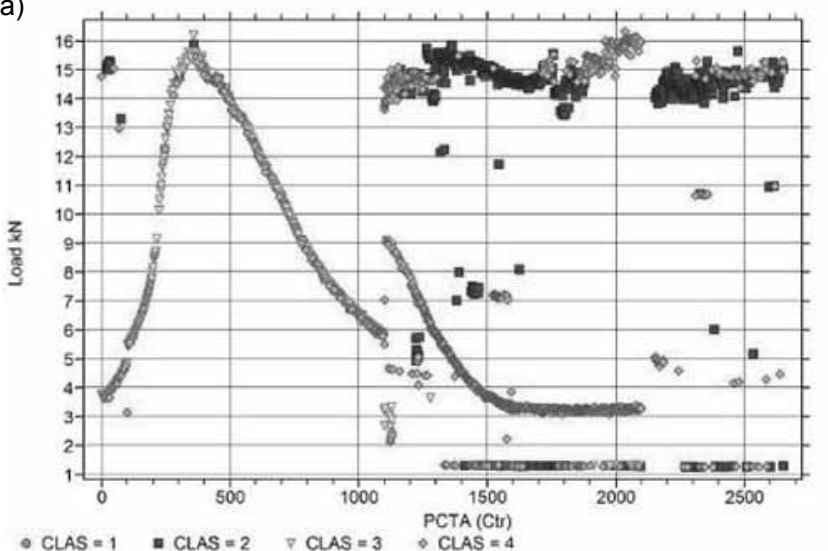

b)

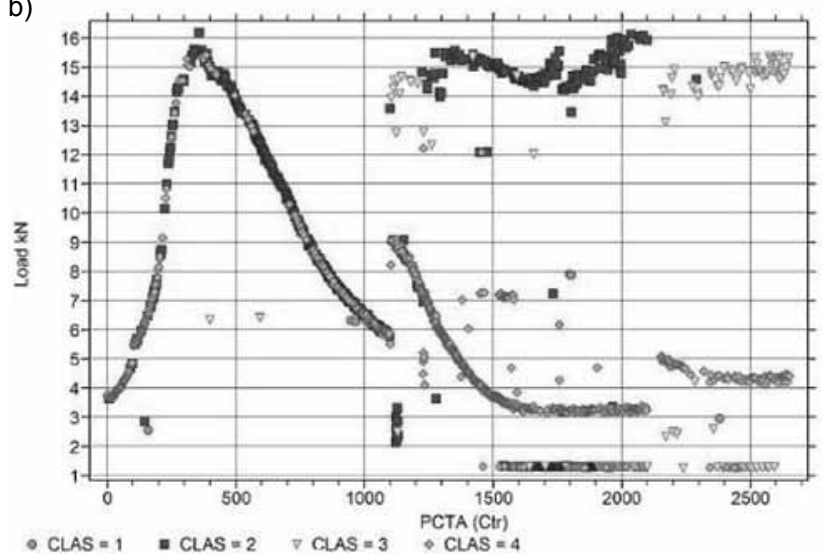

Fig. 12. Przykład analizy sygnałów AE w aplikacji Visual Class dla VS150-RIC (a) i VS75-V (b) (czujniki zamontowane na próbce i zanurzone w cieczy) dla źródła AE wybranego zgrupowania sygnałów (klastera)

Fig. 12. Example of Visual Class analysis of AE signals recorded by VS150-RIC (a) and VS75-V (b) (sensors mounted on the plates \& immersed in liquid) for source in selected cluster zone during fatigue test - used unsupervised learning on single file

\section{Wnioski}

Na podstawie uzyskanych wyników oraz ich analizy można wyciągnąć następujące wnioski:

pomiary metodą $A E$ podczas serii badań zmęczeniowych wykazały, że możliwe jest rejestrowanie sygnałów $A E$ pochodzących $z$ rozchodzącego się pęknięcia zmęczeniowego przez czujniki montowane bezpośrednio w próbkach.

Fale AE pochodzące z pęknięcia zmęczeniowego i przenikające przez ciecz bezpośrednio stykającą się z uszkodzeniem mogą być rejestrowane przez czujniki $A E$ zanurzone w tej cieczy.
Zarejestrowana $\mathrm{AE}$ (parametry wraz z sygnałami AE) została poddana analizie i ocenie, a następnym krokiem będzie wykorzystanie oprogramowania do analizy z wykorzystaniem metody wzorców uczących (pattern-recognition) do identyfikacji zarejestrowanych sygnałów $A E$.

W celu monitorowania stanu konstrukcji badanego obiektu i późniejszej oceny ewentualnych wad konieczne jest, aby móc odróżnić poszukiwane (rzeczywiste) sygnały AE pochodzące z uszkodzenia od tła akustycznego.

\section{Literatura}

[1] Ohtsu M. and Ono K., J. Acoustic Emission, 3, (1984) 69-80.

[2] Nabil Bassim M.: Assessment of fatigue damage with Acoustic Emission, J. Acoustic Emission, 4 (1985) S224-226.

[3] Horrigan P. M., Finn J. F., Tuler F. R., Smith J. H.: Locating Fatigue Cracks by Acoustic Emission Testing, J. Acoustic Emission, 8 (1989) S79-83.

[4] Keinosuke Fukunaga Introduction to Statistical Pattern Recognition, 2nd ed., ISBN 0-12-269851-7.

[5] Baran I., Nowak M., Ono K.: Acoustic emission analysis of the over-straining of pipes in a poly-ethylene reactor, 28th European Conference of Acoustic Emission Testing (EWGAE), Kraków, Poland, Sep.17-19, 2008.

[6] Hutchinson M. Y., He, J. W.: Asymmetric four-point crack specimen, J.Applied Mechanics, 67, (2000) 207-209.

\section{Spotkania Spawalników w 2013 r.}

\section{Warmińsko-Mazurska Biesiada Spawalnicza Olsztyn, 13.06.2013}

Kontakt: Wiesława Bączyk, tel.: 8953510 00, e-mail: olsztyn@rywal.com.pl

II Dolnośląskie Sympozjum Spawalnicze Wrocław, 19.06.2013

Kontakt: Artur Lange, tel.: 7132021 45, Artur.Lange@pwr.wroc.pl

\section{Szczecińskie Seminarium Spawalnicze Szczecin, 5.09.2013}

Kontakt: Katarzyna Rudzka, tel.: 91462 42 75, Katarzyna.Rudzka@pl.linde-gas.com

\section{Kieleckie Spotkanie Spawalników Kielce, 12.09.2013}

Kontakt: Ewelina Janus, tel.: 41368 74 80, Ewelina.Janus@pl.linde-gas.com

XVII Pomorskie Spotkanie Spawalników Gdańsk, 17.10.2013

Kontakt: Iwona Janson, tel.: 5851128 00, Iwona.Janson@pl.linde-gas.com

Materiały konferencyjne zostaną opublikowane w numerze 6/2013 miesięcznika naukowo-technicznego Przegląd Spawalnictwa 